\title{
The Coming of the Projectionettes
}

Women's Work in Film Projection and Changing Modes of Spectatorship in World War II British Cinemas

\begin{abstract}
This article investigates women's roles as cinema projectionists, and transformations in women's spectatorship, in Britain during World War II. Between 1939 and 1945 the British Cinematograph Exhibitors' Association (CEA), among other organizations, encouraged women to train as projectionists when the government conscripted men into the armed forces. The "projectionettes" experienced unequal pay, often chaotic training programs, and patronizingly sexualized portrayals in contemporary press reports. Yet without women projectionists, British cinemas would not have been able to operate during the war. This essay traces their histories and daily working lives through archival materials and the trade press. Moreover, by situating their work in a broader narrative about gendered spectatorship, the article proposes that owing to changing labor conditions, women gained new perspectives through their experiences in the movie theater. Investigating women projectionists is a valuable strategy in a broader reexamination of British film exhibition, points of view, and the proliferation of "women's cinema" during wartime. KEYWORDS British cinema, female projectionists, film exhibition, spectatorship, World War II
\end{abstract}

In December 1940, S. G. Rayment, editor of the British trade publication the Kine Yearbook, noted "a certain interesting development-in the embryo stage at the time of writing" regarding the employment of women as projectionists in cinemas. ${ }^{1}$ At the war's outbreak, the British government began conscripting men into the armed forces, which created a dearth of qualified projectionists. So, for the duration of Britain's involvement in World War II, women worked as "projectionettes" (as they were pejoratively termed in the contemporary press) to keep the nation's cinemas serving their millions of daily visitors. ${ }^{2}$ Maintaining Britain's extensive network of cinemas (by 1939 there were more than 2,300 across England, Wales, and Scotland) was essential at a time when cinema-going was the nation's most popular form of entertainment outside the home, with approximately twenty-two annual cinema visits per capita. ${ }^{3}$ Aside

Feminist Media Histories, Vol. 2, Number 2, pps. 48-71. electronic ISSN 2373-7492. (C) 2016 by the Regents of the University of California. All rights reserved. Please direct all requests for permission to photocopy or reproduce article content through the University of California Press's Reprints and Permissions web page, http://www.ucpress.edu/journals.php?p=reprints. DOI: 10.1525/fmh.2016.2.2.48. 
from a brief, state-led initiative that closed movie theaters in September 1939 for public safety, the government recognized that keeping them open was vital for morale on the home front. However, while politicians and theater managers alike were keen to keep projectors whirring and arc lamps burning across the country, projectionists joined the armed forces and so exhibitors feared closure. Thus, women became essential to Britain's cinema culture in new ways during the war.

Previously employed in picture houses in comparatively domesticated roles, such as usherette or cashier, women entered the noisy, dirty, and technically demanding spaces of the projectionist's "box," rewind room, and sound room to ensure that British audiences could keep calm and carry on going to the movies. Although women played an important role in film exhibition throughout the conflict, men often downplayed their abilities in the operator's box. In a statement that demonstrated the dismissive attitude of the patriarchal cinema industry toward women operators, Rayment claimed that "the coming of the projectionettes will be little more than an emergency measure," merely "another example of the constant effort that is necessary to ensure that the "show must go on.' "' While he was right to forecast that female projectionists would be a temporary, wartime phenomenon, he underestimated the crucial role that they would play in maintaining British cinema exhibition between 1939 and 1945. Moreover, he could not have guessed at the significance of the "projectionettes" in creating a "women's cinema" that was not defined by textual address, but rather women acting as both subject and object within the auditorium.

In this article, I argue that women's increasing presence in the projectionist's box offered the female operators greater access to different, usually masculinized spaces within the cinema. To examine transformations to the gendered activities of spectatorship and work within Britain's wartime picture houses, I first offer a historical overview of the projectionist's role in the cinema industry, and male ambivalence about women operators throughout the war. I go on to examine not only what everyday life was like for the projectionettes during training, but also how attitudes toward them changed during the conflict. Finally, I consider how the female projectionists' invisibility inside the box enabled them to operate beyond traditional boundaries demarcating gender, while also situating women's work in a broader narrative about spectatorship within the auditorium. Drawing on feminist theory, I propose that the history of women projectionists and female viewers 
in wartime cinemas complicates discourses about the gendered, political act of looking when at the movies.

\section{GENDER AND THE LABOR CRISIS IN BRITISH CINEMAS}

Women's labor in a range of roles across international film production has been the focus of substantial scholarship. Some notable examples are the Nordic Women in Film collaboration, the Women and British Silent Cinema website, and the Columbia University-led Women Film Pioneers Project, all of which demonstrate women's varied contributions to production. ${ }^{5}$ Research is beginning to reveal the conditions under which women have worked in cinemas, such as Shelley Stamp's volume on early film exhibition and Laraine Porter's work on women musicians (although so far, scholarship has tended to focus on the period before 1930 and has yet to fully explore women's labor beyond the film studio or set in Britain). ${ }^{6}$ David R. Williams's work on women projectionists in World War I explores how staff shortages in cinemas owing to conscription led to women entering the projection box during the earlier conflict. ${ }^{7}$ While acknowledging that "lady cinematograph operators and proprietors had existed even in the early days of showground cinematographs," Williams examines how during the war, women entered the projection room and manager's office in greater numbers. ${ }^{8}$ My article challenges Williams's claim, however, that these opportunities were only "afforded to ladies in World War One" and "were repeated to a lesser extent in World War Two." I do so by examining the widespread training and hiring of women operators in the Second World War.

While the full extent of women's work in British cinemas has yet to be recovered and explored by film scholars, evidence suggests that at the war's outbreak in 1939, men typically ran the show, holding positions as managers, projectionists, and electricians. ${ }^{10}$ Picture houses were hierarchical workplaces in which gender played a major role in determining employees' access to space. For example, in three London picture palaces designed in 1935 (each of which seated more than one thousand patrons), the number of rooms that female staff members could enter was far lower than the number of rooms open to male recruits. ${ }^{11}$ At the Eldorado Cinema designed for Swiss Cottage in northwest London, male workers had gender-exclusive access to 59 percent of staff-only spaces within the theater; by contrast, women em-employees, not employed ployed had exclusive access to just 3 percent. ${ }^{12}$ Similarly, at a south London auditorium, men had gender-exclusive access to 60 percent of staff rooms compared to I percent for women. ${ }^{13}$ And at the Mayfair on Brick Lane in east London, men could enter 53 percent of workspaces without women, 
while female staff members could enter just 3 percent without men. ${ }^{14}$ In all three cases, the female-only spaces were restrooms and changing rooms. The figures suggest that unless women staff were attending to their appearance or toilette, male employees were inspecting them and their work. Men, meanwhile, worked without female oversight, demonstrating the gendered imbalance in the authority of looking in the cinema as a workplace. The architects' plans also suggest that female workers were confined to public spaces within the cinema (for instance the auditorium or the lobby) alongside paying customers. As a result, women employees occupied a lower status than their male coworkers, who had greater access to private and specialized rooms.

When Britain entered World War II on September 3, 1939, the men-only spaces within cinemas began emptying of staff. Despite women's employment as projectionists being anathema to men working in the cinema industry, managers had to ensure that movie theaters remained open and so were forced to find capable replacements for the projectionists conscripted into government service. Given that the projectionist was "the most important person in the theatre, responsible as he [was] both for picture and sound," quickly training new recruits was a challenging task regardless of the trainees' gender. ${ }^{15}$ That managers had to replace projectionists with projectionettes at a time when men mistrusted women's capacity for skilled work exacerbated tensions.

By November 1939, just two months after Prime Minister Neville Chamberlain declared war, Kinematograph Weekly (aka Kine Weekly) reported that the lack of trained projectionists available to cinemas was a critical problem. ${ }^{16}$ The issue was worst in the nation's industrial regions, where exhibitors not only lost staff to conscription, but also had to compete with a large number of factories when scouting for potential recruits for the projection box. To combat the sudden scarcity of projectionists, union leaders and the trade press began contemplating schemes that might encourage women to train as operators. Leading the movement toward employing female projectionists was the Cinematograph Exhibitors' Association (the CEA, a trade association that represented movie theaters). The CEA urged cinema managers to train and employ women projectionists, although reports stressed that the projectionettes were a temporary measure "for service during [the] war period only." ${ }^{17}$ Moreover, Kine Weekly suggested that usherettes might move from the auditorium into the box to help managers keep cinemas running amid the nationwide staffing crisis. ${ }^{18}$ So great was the shortage that one commentator advocated offering female recruits inflated 
wages to coax them into the industry. ${ }^{19}$ Yet without facilities in place to accommodate a large influx of trainees, cinemas were not equipped to provide proper training even to the women who already worked within the industry (such as usherettes).

Although the labor crisis was a nationwide problem, there was no national scheme to counteract the lack of skilled workers. In other employment sectors, cinemas successfully transformed localized recruitment initiatives into national ones, with Associated British Cinemas (the $\mathrm{ABC}$ chain) rolling out a national drive to train women managers based on a pilot scheme in London. ${ }^{20}$ When seeking projectionists, local CEA branches implemented regional training schemes for women and decided terms of employment on an arbitrary basis and with limited success. Consequently, the industry's response to the predicament remained localized at best, and haphazard at worst. For example, in April 1940 the Bristol CEA division announced that it was establishing a center for training women projectionists that would instruct recruits how to perform an operator's responsibilities over six months of study. ${ }^{21}$ But when the organization publicized its regulated training scheme, one local CEA member revealed "that he was already training one woman" without the union's prior knowledge. ${ }^{22}$ In 1942 yet more disparities emerged among CEA branches. In England and Wales, women working in projection boxes could only qualify as "third" assistants, who answered to seconds, firsts, and the chief operators. The Scottish division introduced a two-tier certificate system that enabled women to assume greater responsibility as second operators. ${ }^{23}$ Upon completing the appropriate examinations, women employees were "permitted to take charge of the operating enclosure," albeit only when a more senior male was present on the premises. ${ }^{24}$ Henceforward, female projectionists could achieve greater seniority and higher pay depending on where they trained.

Further to the CEA's efforts, the Guild of British Projectionists and Technicians discussed recruiting female members (and forcing a change in the organization's constitution to do so) in recognition of women's increasing presence in cinema workforces. ${ }^{25}$ Cinemas placed "situation vacant" notices directly in regional newspapers, which offered local women "good commencing wages and prospects" and "good working conditions" with a major chain. ${ }^{26}$ Starting in 1942, female conscription reduced the number of young women available to theaters and even led to some trained projectionettes being called up to work in other, nationally vital industries. Cinemas soon began to rely on older women. Thus another advertisement required women over thirty to sign up for one week's training, with "club accommodation" and pay " $£_{3} / 5$ upwards." 
In September 1942 the CEA reached an agreement with the Ministry of Labour to limit the number of women projectionists conscripted, with women aged between nineteen and thirty-one only called away from their projectionist jobs if cinemas had a suitable substitute ready. ${ }^{28}$ However, while the efforts of individuals and district organizations attracted some women into the profession, there was never a nationally unified recruitment strategy and exhibitors continued in their struggles to employ projectionists.

The juxtaposition between well-intentioned but ineffective local recruitment and the nationally recognized labor shortage in the operator's box points to an ongoing ambivalence within British culture about women's employment during the war. ${ }^{29}$ On the one hand, female workers were essential to the war effort in general, including cinema exhibition. On the other, women's enlistment in typically male roles (including the technically and physically demanding job of projectionist) challenged the established ideology that the maintenance of femininity was essential for women inhabiting public space. In her work on gender and British cinema in World War II, Antonia Lant examines the government's various attempts to preserve gender distinctions when women joined the workforce. She describes how the government subjected cosmetics to special rationing to encourage women to maintain a feminine appearance, and conflated the words "national" and "home" to position women working for the war effort within an expanded domestic sphere. ${ }^{30}$ But despite the government's efforts, many men remained opposed to female recruitment owing to fears about job losses for returning soldiers, women's perceived incompetence at carrying out skilled tasks, and wage cuts as a result of (lower-paid) women driving down salaries. In a bid to assuage fears about pay in the cinema industry, the CEA introduced equal pay for trained male and female operators, thus ensuring that contracts for women were not prejudicial to male projectionists who wanted to resume their prewar duties after demobilization. ${ }^{31}$ While the CEA's decision was intended to benefit men, a by-product of the pay scale was a semblance of equality for women.

Wages were perhaps one of the contributing factors that helped female recruits overcome both patriarchal opposition to women entering the box and the industry's chaotic attempts at recruitment, as by 1943 women operators were commonplace in British cinemas. That year, alongside the CEA's imposed salary increases and the continuation of sponsored training initiatives, the major cinema chain Gaumont set up schools for women operators across Britain, with centers in Birmingham, London, Yeovil, Liverpool, and Glasgow. ${ }^{32}$ While the centers were organized regionally—representing the midlands, south, southwest, 
northwest, and Scotland, respectively-Gaumont's schools adhered to a single nationwide curriculum.

Also in 1943 the government's Ministry of Labour advised that cinemas "must expect a heavier call-up of women employees," and that (with the possible exception of projectionists) "all women within the age limits affected ... are likely to be directed into other employment." ${ }^{33}$ Consequently, girls as young as sixteen, women over thirty-one, and those who were married with children became eligible for training to make up the shortfall, as qualified female projectionists faced conscription. ${ }^{34}$ The continued shrinking of the workforce at the government's behest presented a major problem for cinema owners. But increased conscription had a positive impact on female employment in movie theaters because the labor shortage (and, possibly, improvements to training schemes) led to women successfully certifying as "firsts" across Britain. ${ }^{35}$ While still subject to a male chief operator remaining on site, women now took sole charge of the projection box and so enjoyed greater authority and autonomy at work. In an industry traditionally populated by male employees, Britain's wartime women gained entry not only to projection boxes, but also to sound rooms, rewind rooms, and many of the other cinema spaces that were the preserve of men before the war. Nevertheless, while female labor transformed cinemas into more gender-inclusive workplaces, the CEA and the unions, including the National Association of Television and Kinema Employees (NATKE), were in agreement that women's employment was "an emergency measure to meet the contingencies resultant upon war." ${ }^{36}$ As such, the women who trained as projectionists faced precarious future employment.

\section{PROJECTIONETTES: IN THE BOX AND ON THE PAGE}

Everyday life for the projectionettes involved trying to gain in just a few months, or even weeks, the technical expertise that men typically built up over three to four years. An industry insider suggested that at instructional centers such as those run by Gaumont, women "would be trained for certain jobs in production, processing and projection. Although it takes several years for any film technician to become fully qualified, after three or four months at the school these students would have gained sufficient knowledge to do useful work under the supervision of the remaining 'key' men left in the Industry." ${ }^{37}$

The commentator, writing in Kine Weekly, emphasized that, even after qualifying, women would still work "under" more experienced and authoritative men, who were likely too old for conscription and still working in cinemas. Another writer in the trade journal anticipated that the role of projectionist 
would likely appeal to "girls" who wanted work of a "quieter character" than the "noise and nerve-rack" of the factory. ${ }^{38}$ Inside the box, however, women carried out heavy lifting and dirty tasks such as operating projectors, oiling and greasing machinery, changing spools, rewinding film, and splicing and cementing celluloid. As a result, government officials placed projectionists on a list of occupations that received extra clothing rations due to the likelihood of wear and tear to garments. ${ }^{39}$ Furthermore, even experienced projectionists acknowledged the difficulties and dangers inherent in the job. For example, one described how, under wartime conditions, technicians in the cinema had to be "dedicated to that particular job," while another recounted dashing between cinemas in the dark with cans of newsreels that were shared owing to shortages of film stock. ${ }^{40}$ Another experienced male operator writing about the profession in his local newspaper told readers that the working conditions and long hours contributed to the "thanklessness of [the] occupation," suggesting that the projection box was far from offering shy young girls the chance to escape the "nerve-rack" of factory life. ${ }^{41}$

In a rare Kine Weekly interview with actual projectionettes, operators Marion and Alma described their training as "grueling." ${ }^{\text {"2 }}$ Marion and Alma were typical of the first cohort of female operators in that they were young (aged between eighteen and twenty-two), referred to as "girls" in the trade press, and trained at a local cinema. The schooling provided by cinemas varied depending on the attitudes of the manager and chief projectionist, with some employers offering only a week's training and others, including Gaumont, demanding longer attendance. ${ }^{43}$ One theater described a militarized selection process that made great mental as well as physical demands on the young women who hoped to undertake training:

The first elimination of recruits was almost automatic. We escorted them deliberately through the theatre, pausing awhile to watch the screen and sense the atmosphere, and then bluntly out into the cold and up the iron stairs into the box, with the monitor blasting much louder than was usual. That procedure weeded out the "film fan" type. The others stood at the back of the box, with strict instructions to be neither seen nor heard, for a solid hour, through three or four changeovers. Those with headaches soon faded away. Those who were left were invited to come back next morning and use things cold. These we took on, feeling none was taken in. For some days, until they got thoroughly used to their surroundings, we let them do nothing more than watch through an idle porthole for changeover cues. . At intervals the rewinding was watched, and, in the mornings, a discarded trailer 
was made the victim of countless cuts and joins, with Movietone ink silencers as requisite. They then passed to actual inspection of films during rewinding. After about a week of this, several of them felt able to tackle a new program straight out of the transit cases. ${ }^{44}$

During the weeks that followed, the chief operator gave the girls "occasional hints about such things as ghost, racks, focus, and discoloration.” ${ }^{45}$

The training schools established by the CEA and companies such as Gaumont paid greater attention both to the skills required in the box and to the women's learning. The Birmingham School, one of the first opened by the CEA, had a robust curriculum and provided successful trainees with a certificate of competence. More than sixty women qualified as third operators within its first year. ${ }^{46}$ In Holborn, London, six men oversaw Gaumont's facility and reportedly had "remarkable success" providing the circuit with "a steady stream of projectionists to replace men. ${ }^{37}$ An Ideal Kinema report stated that "the curriculum of the school is wide," with specially designed facilities ensuring that the women gained theoretical as well as practical skills. For example, lamp training occurred in a lecture theater, while in an adjoining recruits, not girls room girls practiced "striking the arc." Trainees could "throw" the picture on a "baby" screen that simulated the distances in a regular theater, and in another room women learned how to use portable $35 \mathrm{~mm}$ and $16 \mathrm{~mm}$ projectors for naval shows. ${ }^{48}$ Rigorous training was crucial in a profession that required both technical skill and expert knowledge, such as holding celluloid with a particular grip that avoided "dirtying the film," and detecting "any perforations or other damage." ${ }^{\not 9}$ To successfully pass Gaumont's strict examinations and make it to the box, trainees had to quickly acquire and implement practical skills, alongside learning about electrics and sound equipment.

While no woman could qualify as a chief operator, at the London school the recruits achieved the status of "first" assistants and could therefore manage the box autonomously. ${ }^{50}$ Thanks to union interventions regarding salaries, any women who worked as "firsts" received the same pay as the men that they replaced within six months of taking up the post. ${ }^{51}$ Wages remained a debating point throughout the war, with Kine Weekly assuring readers that "the comparative small number of women at present employed in the film industry is not due to any prejudice," but rather attributable to ongoing disputes about equal salaries. ${ }^{52}$ As George Elvin, secretary of the Association of Cine Technicians, stated, "We have no objection to women taking up any technical position in the Industry so long as they receive the rates laid down by the unions. Already 
there are a number of girls learning processing in the laboratories, and they are receiving the same rates of pay as the men." 53 The recruits' pay during their three months of training was roughly twenty-three shillings per week, rising to thirty shillings when students qualified as third operators and began working in the box as "supplementary" staff. ${ }^{54}$ Given that female operators suffered a comparative lack of experience due to the short and intense nature of their training, the parity in wages could be interpreted as an advantage they enjoyed. Yet reports from 1944 indicate that female operators did not always receive equal pay, for in a dispute with the NATKE over wages the CEA suggested that men receive three pounds and ten shillings per week compared to just two pounds Association for women. ${ }^{55}$ Despite the association's earlier protestations about ensuring equal salaries, the cinema industry remained gender-biased with regard to pay.

Contributors to the unions and the trade presses also sought to undermine the women's work. At a NATKE meeting to discuss the terms of female operators' employment, one representative suggested that "not many girls could take charge of the box," while another said that a qualified operator had to be on site to deal with emergencies and "would not leave a girl in charge." 56 In a separate article, a critic of the projectionettes feared that, in the event of being left alone in the box, "girls" "might be seized with a momentary panic and do just the wrong thing." ${ }^{57}$ Apparent hysteria was compounded by girls' alleged inability to think independently. An experienced chief operator and his friends likened the female trainees' work to "monkey play" because "they did just what they were shown." He called it the "limitation of imitation." Another correspondent claimed that "the work to be done is mere imitation," suggesting that women could mimic men but not equal them. ${ }^{59}$ Yet another insisted that "the problems which have to be faced and handled by a chief or second projectionist with four or five years of experience cannot be left in the hands of the average woman who takes up duties in the box." ${ }^{60}$ The implication was that the projectionettes were young and silly women who could not be trusted to show initiative.

In addition to trivializing the projectionettes' abilities within the cinema, Kine Weekly and Ideal Kinema used language that undermined female employees. This was probably due in part to the lack of female journalists working for the male-oriented industry journals. Men wrote articles about the projectionettes and framed the reports in which the women gave interviews. In one example, W. J. Gell used feminine imagery to describe projection both as the "heart of the show" and "the lifeblood of successful [movie] theatre operation." ${ }^{61}$ His references to the "heart" and "lifeblood" reconfigure the traditionally male space of the projection box as a female one by associating it with the emotion and interiority 
commonly attributed to women. Moreover, when writing about female operators, the term projectionette served as a marker of femininity and otherness distinct from the traditionally masculine work of the projectionist, enabling male journalists to delineate women's and men's labor. In a further bid to maintain the distinction between masculine and feminine work, reporters consistently labeled women as "girls" regardless of the operators' ages, and frequently alleged that female operators carried out domestic tasks in the box.

Antonia Lant describes how any workspace in Britain during the war (be it a cinema, cipher room, or munitions factory) carried with it the connotation of domesticity because labor undertaken there was conducted on the "home" front, which legitimized women inhabiting a usually masculine environment. ${ }^{62}$ As such, references to sewing and household chores in connection with the projection box were common. Women reportedly kept projection rooms "spotlessly clean and spick-and-span" and, despite working long hours, were just as enthusiastic "as when they first 'threaded-up," whereby the mechanical term "threading up" was made to allude to sewing. ${ }^{63}$ R. Howard Cricks, a regular contributor to Ideal Kinema, noted that while the "average girl [was] deficient in mechanical aptitude," she was "no more awkward than the average man would be with a needle and thread." ${ }^{64}$ Alfred G. May, the Birmingham labor liaison for the CEA, argued that in some cases female trainees' preoccupations with household chores were actually a distraction from their work. He claimed that as "a general rule, women ... seem more concerned with their domestic duties than with punctual and consistent attendance" in class. ${ }^{65}$

The trade press further undermined women's authority in the projection box by casting female operators as objects of, or subject to, sexual desire. In one instance, in an article aimed at aiding women's training, a male operator assured female trainees that "making up" (a term referring to splicing reels of film together) had "nothing to do with a lovers' quarrel, but the very important job on change day." Also detracting from the female operators' skills was a rare image of a projectionette in the form of an Ideal Kinema cartoon that sexualized the role (fig. I). ${ }^{67}$ She appears in a short dress, complete with lipstick, high-heeled shoes, and seamed stockings (that last presumably purchased on the black market, given the shortage of silk, which was necessary for making parachutes). The cartoon projectionette is romanticized according to a patriarchal fantasy, and her appeal for approval from the senior, male chief operator for whom she is completing work suggests a dynamic in which the female worker happily submits to the superior male. He says, "Now that's what I call neat and careful rewinding," to which she responds, "Yes, chief." ${ }^{\prime \prime}$ That the illustrated female 


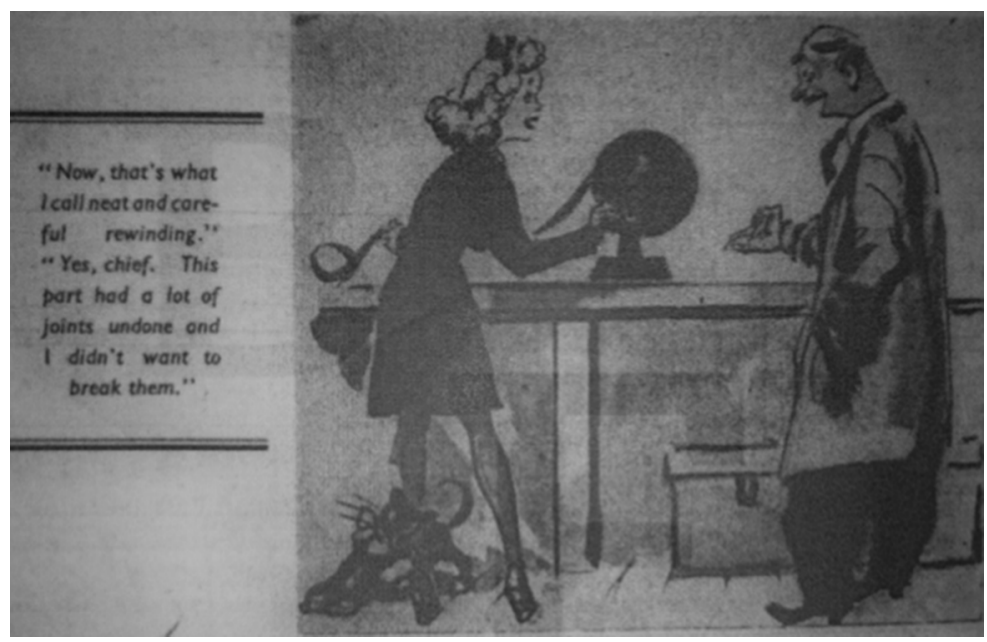

FIGURE 1. A sexualized and domesticated projectionette, complete with pet cat, winds film in a trade press cartoon. (Ideal Kinema, September 13, 1945, xvii)

projectionist resembles an usherette (an earlier iteration of female cinema worker that predated the war and the labor crisis) or a maid, both of whom are associated with a domestic environment, likely appealed to patriarchal—and nostalgic-conceptions of femininity. Richard Farmer suggests in his work on women projectionists that during the war, "many men found it difficult to distinguish a woman from the clothes she wore," and that "flimsy" female attire contributed to the view that women were "unsuitable" for work in the operator's box. ${ }^{69}$ Yet the caricature looks nothing like the actual women who operated projection equipment in uniforms consisting of utilitarian overalls and hard hats (figs. 2 and 3 ).

Of course there were some supportive voices who championed the women's work, and, as the government persisted in threatening the cinema industry with further labor cuts, attitudes toward female labor in the trade press improved. For example, in 1941, the CEA recognized female operators's significance in maintaining film exhibition and fought for women to remain in projection boxes rather than retrain for government service. ${ }^{70}$ Some CEA members reported that women successfully operated the box alone and, in support of women projectionists, a Mr. McLaughlin went so far as to remind his colleagues that "while there were some good men operators, there were also some very bad ones." ${ }^{.71}$ Moreover, in the face of widespread criticism about the projectionettes, the manager at the Manchester Rialto stated that with two female first 


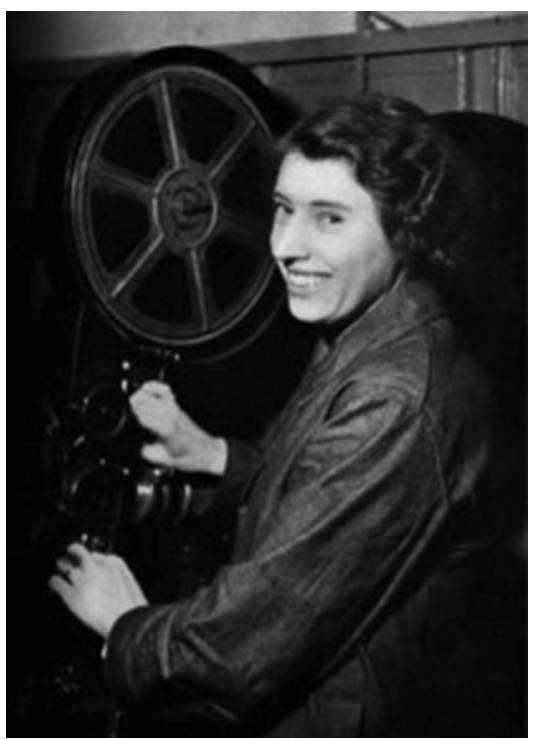

FIGURE 2. Flo Grinswood, a projectionist at the Kinema West Ham in London, operates machinery in sturdy overalls.

(Photo by Kevin Wheelan, I940s, reproduced by Charles S. P. Jenkins at East End Memories.)

projectionists "there [had] been no relaxing of the high standard of efficiency which [had] always characterized [the] house."72 In 1942 a Kine Weekly article further emphasized women projectionists' "pivotal" roles in ensuring that cinemas remained opened during the war. ${ }^{73}$ To challenge the government's decision to remove trained women from projection boxes, front-page headlines stressed women's significance to the industry by replacing the labels "girl" and "projectionette" with "women" and "female projectionists." And the words of the manager at the Dover Regent Cinema offered evidence to rebut ongoing criticism of women in the box, claiming that his female operators provided the "perfect answer to any exhibitor who argues that women do not make good projectionists." 74

That is not to say that the trade press validated all women projectionists, as older female operators often bore the brunt of patronizing comments. One columnist wrote that, as expected, "the younger women with more receptive minds than those of thirty or over have picked up some of the elementary technical duties comparatively quickly." However, he did not expect "that older women will possess so widely that receptivity to new ideas." 75 Lant proposes that 


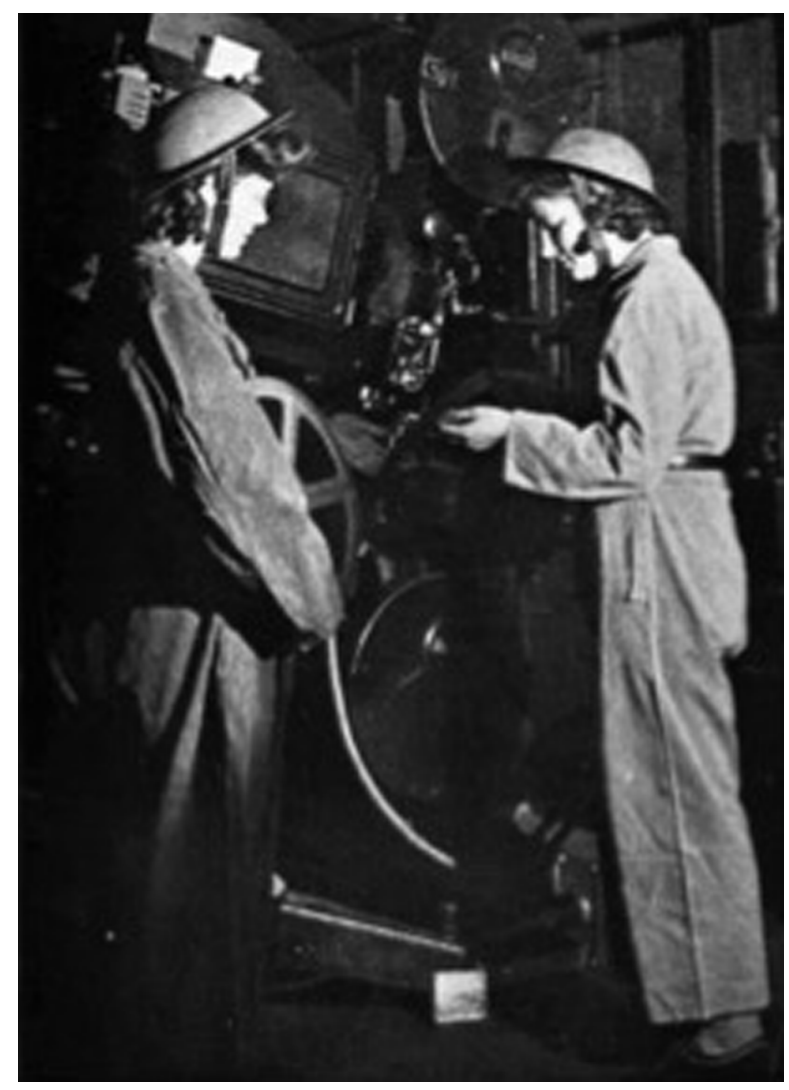

FIGURE 3. Two women operators at the Granada Harrow, London, thread the projector while wearing practical overalls and hard hats. (Photo by Kevin Wheelan, 1940s, reproduced by Charles S. P. Jenkins at East End Memories.)

during wartime, women filmgoers had "to make sense ... of a range of representations of themselves: from being inessential to national identity, to being central to it, to threatening to it." ${ }^{\prime 6}$ This is true of female operators, for while younger women became "central" to cinema's continuation in wartime, the trade press represented older women as "inessential" or even "threatening" in their perceived ineptitude. Thus there was always an apparent need — whether owing to a lack of training, youth, or older age-for superior male cinema employees to watch over the projectionettes and uphold dominance. Even the complimentary manager at the Manchester Rialto stated that he had "always [felt] a thrill of admiration" when he watched the women projectionists make changeovers. He claimed that 
he would "like many projectionists of twenty-three years' experience to witness this performance."77 The manager's comments in support of female operators were likely meant to (and likely did) improve the projectionettes' status within cinemas run by Kine Weekly's readership. However, his invitation to other, more experienced men to inspect the women's work alludes to a power dynamic in which female operators were always overseen.

\section{PROJECTING AND WATCHING FILMS IN WARTIME}

As a consequence of the national emergency, cinemas admitted female operators to exert authority over projected images as part of predetermined programs. And these dramatic changes to the demographics of the workforce inspired dramatic language: one critic declared that women were "invading" the projection room. ${ }^{78}$ Throughout the war, the box remained a contested site in which men and women played out a gendered war over looking and moving. And it was not just the projection room they were invading, but other rooms within the cinema that traditionally housed men's labor. Women worked as camera operators, still photographers, cinema evaluators, and managers. ${ }^{79}$ With regard to women's access to space in movie theaters (which in 1935 was limited to just 40 percent of one London picture house), wartime labor conditions improved female mobility within the cinema. ${ }^{80}$ In addition, the dynamics of looking altered in the auditorium owing to the genesis of all-female production units, women projectionists screening films, and predominantly female audiences going to cinemas (they represented approximately 70 percent of cinema attendees). ${ }^{81}$ Inside the projection box, there were opportunities for women to control the projected image, and, in doing so, assert their "right to look." $" 2$

In analyzing gender and visual culture, scholarship typically suggests that men observe and women are observed. ${ }^{83}$ In theorizing looking as gendered activity, scholarship not only distinguishes between active men (who look) and passive women (who are looked at), but also divides space into binary, gendered spheres, with men inhabiting the public, visible world, and women the private and invisible. ${ }^{84}$ Of course, so neat a dichotomy works better in theory than in practice, for women have always worked in, and encountered, the public sphere. But in twentieth-century British society there was a pervasive anxiety about women inhabiting the public realm, with newspapers throughout the 1920s and I930s frequently depicting visible women who ventured outside the home as victims of cinema fires and train crashes. ${ }^{85}$ In wartime, changing labor conditions began to blur demarcations between the traditionally gendered spaces of 
the workplace and the home (highlighted by Lant's analogy between the domestically figured "home front" and nationally important workplaces such as factories and military bases that opened up to women). ${ }^{86} \mathrm{I}$ argue that cinemas' employment of female operators, alongside transformations to the workforce more broadly, led to women simultaneously performing in both the visible, public sphere and the concealed and private one, which in turn complicated how women looked while at the cinema.

One the one hand, women increasingly took up exhibition work that necessitated actively observing their environment rather than passively being observed-for instance projecting film and watching for changeovers. And, as projectionists, women controlled the speed, luminosity, quality, and sound of every film screened during their shift (although, unless there was a female manager, women's authority over the image was limited to projecting a particular print rather than determining the program). Stationed above the audience and supervising how the picture appeared on-screen, women gained the "right to look" from a new perspective within the cinema. The "female gaze" in British wartime cinemas therefore expanded to include not only women patrons in the theater looking at the screen, but also female operators working in the box.

Furthermore, the projectionettes determined the view of everyone in the auditorium, including any male patrons, while remaining invisible within the projection room. Aside from the occasional visual representation of female operators (such as the aforementioned cartoon), they remained largely out of public sight and so avoided objectification. It was the women's work, rather than their bodies, that, in the words of a male projectionist, "was there for all to see," which challenged the notion that the female form served the male gaze when inhabiting the public sphere. ${ }^{87}$ While projectionists bemoaned the pressures arising from their profession ("our mistakes cannot be torn up and thrown into the waste paper basket unobserved"), film projection enabled women to carry out their work without revealing their appearance to spectators. ${ }^{88}$

On the other hand, the female operators' invisibility inside the box also perpetuated the stereotype of the concealed, private woman carrying out domestic chores. The projectionettes gained access to male space, but within the confines of the projection box the work was repetitive, tedious, and, in the trade press at least, analogous to tasks such as sewing. ${ }^{89}$ Additionally, the women still ultimately looked up to men, for although the female vantage point in the operator's room was both a literally and figuratively elevated one, male chief operators always presided over the box. Female "firsts" could run the show without constant supervision, but chief operators were always present on site and 
took final responsibility for film exhibition. As Christine Gledhill and Gillian Swanson point out, wartime policies "sought to mobilize women for the war effort while at the same time seeking to frame that mobilization in terms that would retain the conventional roles and meanings associated with women." Consequently, the projection box could accommodate women who looked out into the auditorium as men had done because superior male operators always oversaw the projectionettes. The tensions between women's concurrent liberation and confinement within wartime cinemas are further emphasized by the lack of material evidence of the projectionettes now available in archives, as female-authored testimonies from the period are hard to find. With most stories about women projectionists and employees in the film industries originating from men, female operators, who gained both greater mobility and autonomous spectatorship within the movie theater, did not gain a public voice.

In analyzing how the patriarchal British media palatably framed women's mobilization for the British public, Lant proposes that to maintain the differentiation between male and female spectatorship, vision was "re-stratified" along gendered lines during the war. ${ }^{91}$ As such, the air became a masculinized sphere, accessed almost exclusively by male pilots who could survey the ground from aerial vantage points. Meanwhile, women stayed "close to the land, on the territory vacated by men, actively supporting the reign of the upper domain by their work and the direction of their look." ${ }^{92}$ Women were plane spotters, firewatchers, signalwomen, batswomen, and map readers, who all observed the world around them while looking upward toward male superiors. For example, in an Auxiliary Territorial Service (ATS) advertisement and another promoting factory work (Women of Britain Come Into the Factories), women occupied traditionally masculine roles, as female equivalents to army and munitions workers, respectively. ${ }^{93}$ In both cases, the female figures look up at the sky, with the factory worker stretching her arms out toward the airplanes passing overhead as if to acknowledge that her employment is in the service of the male air force. Join the Women's Land Army, a poster encouraging women to join the Women's Land Army (a "healthy, happy job"), roots the female body on the earth. ${ }^{94}$ All three illustrations position female bodies firmly on the ground with their eyes generally pointed skyward, and represent men inhabiting the space above and women the space below — an early allusion, we might say, to the so-called glass ceiling. However, whereas Lant describes a vertical re-stratification that caused women to gaze from the ground upward, I propose that the transformation was across a horizontal plane. Changing labor conditions figuratively lifted the vertical boundaries that demarcated male and female spaces within 
cinemas-for example, the walls that enclosed operators' boxes-and enabled women to enter the projection room. A horizontal plane instead delineated the hierarchy of superior males (who were positioned above) and inferior female staffs (who were stationed below) to counteract the disappearance of vertical borders within the picture house. ${ }^{95}$ Thus women gained access to new spaces within the cinema but were still required to look up to men within the movie theater.

In his work on women, gender, and nationalism in wartime, Matthew Evangelista highlights ongoing debates about women's roles during conflict, whereby some scholars "see nationalist movements as a vehicle for improving women's status" while others "associate militarized nationalism with increasing gender inequality." ${ }^{96}$ Certainly working in the projection box during the war offered women new ways of looking in, and moving through, the movie theater, where they were positioned "high up on the top floor" in the box. ${ }^{97}$ Even in the often-critical trade press, women operators were acknowledged as the force that "may be able to keep [the] industry alive." 98 But despite the female operators' new perspectives behind the projectionist's window, men restricted their opportunities for promotion, and the projectionettes encountered degrading language from male colleagues and objectification in the trade press. Whether in the form of the chief operator or the RAF flying overhead in a recruitment poster, there was still a limit to how, where, and by what means a woman could look.

\section{CONCLUSION}

The "coming of the projectionettes" did not instigate a lasting transformation in women's roles within British cinemas. ${ }^{99}$ Patriarchal concerns about employment, including wages and the availability of jobs after the war, played a major part in preventing female operators from remaining in the box after demobilization, with CEA spokesman May stating, "It is impossible for me to promise any woman employment when peace time comes again." ${ }^{100}$ Even before the war's end, cinema managers were advertising for "boys," rather than women, to train as projectionists. ${ }^{101}$ As if to officially end the phenomenon, Kine Weekly announced that a "properly coordinated" male recruitment drive was necessary, as "large numbers of women who were at present employed in the Industry would eventually be leaving." ${ }^{102}$ So few projectionettes remained in their posts by September 1945 that there was another shortage of skilled labor in the field. ${ }^{103}$ The cinema industry's confused, and often localized, approach to training women in the box not only contributed to the labor crisis during the war, 
but also perpetuated the problem afterward. Thus in 1945, as in 1939, women's access to space and rights to look within cinemas were limited because of their gender.

While temporary, changes in wartime exhibition and employment practices that enabled women greater access to space and vantage points within the movie theater were indicative of broader shifts in attitudes toward women and their roles in society. Throughout the conflict, there was a proliferation of stories enunciated by women in the British media that opened up new, figurative spaces for women to intervene in public life. ${ }^{104}$ Women-authored newspaper articles and female characters in films and on the radio all spoke to female audi-women, not female ences. In particular, women occupied multiple viewing positions both on- and audiences offscreen within cinemas, and watched movies with female-centric narratives. Judith Mayne, in her work on spectatorship, contends that "the act of watching a film means subjecting one's self to the power of another vision." ${ }^{105}$ During the war, it was increasingly likely that the "other" vision, belonging both to another person and a figurative other, had a female origin, whether channeled through a character or a voice-over on-screen, or a projectionist within the cinema. Thus, while the projectionettes remained largely out of sight-both within the movie theater, where they were concealed in the box, and in histories of cinemagoing-they offer us now an opportunity to reinvestigate both the gendered politics of spectatorship and the significance of women's work and "women's cinema" in World War II.

ReBECCA HARRISON is a lecturer in British cinema at the University of East Anglia. Her research examines how cinema both shaped and represented encounters with modernity in British culture from the late nineteenth to the mid-twentieth centuries. Her work also investigates gender, national identity, and wartime filmmaking and exhibition practices. A monograph based on her research, From Steam to Screen: Cinema, the Railways and Modernity, is forthcoming from I. B. Tauris.

\section{NOTES}

I. S. G. Rayment, Kine Yearbook (1940), 12. Women had been employed as projectionists in limited numbers before and during World War I, although the practice was not commonplace. See David R. Williams, "Ladies of the Lamp: The Employment of Women in the British Film Trade During World War I," Film History 9, no. I (1997): 116-27.

2. There were two distinct types of women projectionists in Britain during World War II: in the militarized Auxiliary Territorial Service and Women's Auxiliary Air Force (where women showed mainly instructional $16 \mathrm{~mm}$ films on portable projectors) and in cinemas (in which female operators screened $35 \mathrm{~mm}$ feature films). There were many differences between the two roles, including regulation, pay, machinery, training, 
and the environments where women screened the films. This article focuses on female projectionists working in the entertainment sector of the cinema industry.

3. There were 21.5 cinema visits in Britain per capita in 1935 (this figure continued to increase until it peaked in 1946). See Linda Wood, British Films 1927-1939 (London: BFI Information Services), I20-23, http://www.bfi.org.uk/sites/bfi.org.uk/files/downloads/ bfi-british-films-1927-1939.pdf, accessed August 18, 2015.

4. Rayment, Kine Yearbook, I2.

5. Nordic Women in Film, http://www.nordicwomenfilm.com/Om.aspx; Nathalie Morris and Claire Watson, Women and Silent British Cinema, https://womenandsilent britishcinema.wordpress.com/contact-us/website-credits/; Women Film Pioneers Project, https://wfpp.cdrs.columbia.edu/about/.

6. Shelley Stamp, Movie-Struck Girls: Women and Motion Picture Culture after the Nickelodeon (Princeton, NJ: Princeton University Press, 2000); Laraine Porter, "Women Musicians in British Silent Cinema Prior to 1930," Journal of British Cinema and Television I0, no. 3 (2013): 563-83.

7. Williams, "Ladies of the Lamp."

8. Ibid., I19.

9. Ibid., 127 .

Io. In his work on labor in British movie theaters during World War II, Richard Farmer describes how "Britain's cinemas were run by men." Richard Farmer, The Utility Dream Palace: Cinemas and Cinemagoing in Wartime Britain, 1939-I945 (Manchester: Manchester University Press, forthcoming).

II. To collect the figures, I calculated the total number of private, staff-only rooms found within each cinema. Male-exclusive rooms are staff rooms that women typically could not enter, or did not enter without invitation (including the operator's box, electrician's rooms, and manager's office). Female-exclusive rooms are staff areas typically only accessed by women. All other rooms (such as staff canteens) might be open to both men and women.

I2. Robert Cromie, architect, architectural drawings, Regency Parade, Eldorado Cinema, Odeon Cinema, Adelaide Road, Finchley Road, Upper Avenue Road, Hampstead Met: Building Act Case File (Cinemas, Flats and Petrol Stations), London Metropolitan Archive, 1935. Of a total of thirty-two staff rooms, nineteen were male only, and one was designated women only.

13. William R. Glenn, architect, architectural drawings, Old Kent Road, London Metropolitan Archive, 1935. Out of a total of fifteen staff rooms, nine were men only, and one was for women only.

I4. Leslie H. Kemp and Tasker, architects, architectural drawings, Mayfair Cinema, Brick Lane, I-2 Osbourne Place, Stepney Met: Building Act Case File (Cinemas), London Metropolitan Archive, 1935. Out of a total of fifteen staff rooms, eight were for men only, and two were for women only.

I5. "The Observation Window: Projectionists and the Army," Kinematograph Weekly, October 31, 1940, 30.

16. "Exhibitors Face Dearth of Projectionists," Kinematograph Weekly, November 23, 1939, I. 
17. "CEA Urges Employment of Women Projectionists," Kinematograph Weekly, September 7, 1939, I.

18. "Exhibitors Face Dearth of Projectionists," Kinematograph Weekly, I.

19. Ibid.

20. "A Bold ABC Experiment," Kinematograph Weekly, June 13, 1940, I. That the experiment was a "bold" one is significant because women managers were, like women projectionists, treated differently depending on their location. Other wartime reports in the British trade press about the rise of female managers imply that women running cinemas were not commonplace. During the war, Miss Doris Ashton (a former cashier) became "the first woman kinema manager in Lancashire" in the north of England. As further evidence of the female manager's novelty, in the northern town of Scarborough, local authorities denied a woman the opportunity to run a cinema when police objected to her holding the license, preferring a male manager. See "Names in the News," Kinematograph Weekly, October 31, 1940, 27; and "Control of Kinema Refused to a Woman," Kinematograph Weekly, October 3, 1940, I.

21. "Training Centre Aim for Women in Bristol," Kinematograph Weekly, April I8, I940, I.

22. Ibid.

23. "Women Projectionists in Scots Kinemas," Kinematograph Weekly, April 2, 1942, 20. 24. Ibid.

25. "Guild Discusses Admission of Service Members: Suitable Women for the Box," Kinematograph Weekly, June 5, 1941, 22.

26. "Situation Vacant," Lincolnshire Echo, January 23, I942, 2.

27. "Situations Vacant," Northampton Mercury, February 6, 1942, 8.

28. "Deferment of Women Projectionists," Kinematograph Weekly, September 17, $1942,9$.

29. As such, cinemas' chaotic employment of women operators in World War II was similar to that described by Williams in World War I. See Williams, "Ladies of the Lamp," I2O-22.

30. Antonia Lant, "Prologue: Mobile Femininity," in Nationalising Femininity: Culture, Sexuality and British Cinema in the Second World War, ed. Christine Gledhill and Gillian Swanson (Manchester: Manchester University Press, 1996), 24, 17.

31. "Substitute Projectionists Plan," Kinematograph Weekly, July I, 1943, 38.

32. Alfred G. May, "More Women Projectionists Needed Now: Urgent Problem of Good Training," Kinematograph Weekly, January I4, I943, 60.

33. "Heavier Call-Up: Women Cinema Workers," Aberdeen Journal, January 23, $1943,3$.

34. May, "More Women Projectionists Needed Now," 60.

35. Ibid.

36. "Substitute Projectionists Plan," Kinematograph Weekly, July I, I943, 38.

37. "Technicians Called Up: How to Fill the Gaps," Kinematograph Weekly, April I7, 194I, I.

38. "The Observation Window: A Projectionist Shortage," Kinematograph Weekly, December 26, 1940, I5. 
39. "The Observation Window," Kinematograph Weekly, September 17, 1942, 31.

40. Mickey Hickey, projectionist and sound recordist, BECTU History Project interview; Peter Stroud, projectionist, BECTU History Project interview no. 293.

4I. H. H., "The Editor's Letter Bag-Cinema Contrasts: Plea for the Projectionists," Nottingham Evening Post, March 9, 1940, 5.

42. "Projectionettes on the Duty Rota: Operating and Repair Work," Kinematograph Weekly, June 19, 1941, 28.

43. "Employment Offered," Sunderland Daily Echo and Shipping Gazette, March 24, 1942, 6 .

44. "Training Projectionettes: Encouragements and Disappointments," Ideal Kinema, June 17, 1941, v.

45. Ibid.

46. "School for Women Operators," Kinematograph Weekly, July 23, I942, I.

47. “Training Women as Projectionists," Ideal Kinema, September 10, 1942, xi.

48. Ibid.

49. R. Howard Cricks, "The Art and Science of Handling Films," Ideal Kinema, May 8, 194I, v.

50. "Training Women as Projectionists," Ideal Kinema, xi.

5I. "Women Projectionists in Scots Kinemas," Kinematograph Weekly, 20.

52. "Technicians Called Up: How to Fill the Gaps," Kinematograph Weekly, I.

53. Ibid.

54. "Training Projectionettes: Encouragements and Disappointments," Ideal Kinema, v.

55. "Wage Discussion Sensation," Kinematograph Weekly, May 18, 1944, I.

56. "Women Operators," Kinematograph Weekly, August 19, 1943, II.

57. "The Observation Window: Training Projectionettes-An Engineer's Book for Beginners," Kinematograph Weekly, July 23, 1942, 45.

58. "Training Projectionettes: Encouragements and Disappointments," Ideal Kinema, v.

59. "Projectionettes on the Duty Rota," Kinematograph Weekly, 28.

60. "Trade Alarm at Labour Shortage," Kinematograph Weekly, May 22, I941, I.

61. W. J. Gell, "The Art of Presentation: Good Projection Vitally Needed," Kinematograph Weekly, January I4, I943, 48.

62. Antonia Lant, Blackout: Reinventing Women for Wartime British Cinema (Princeton, NJ: Princeton University Press, 1991), 44.

63. Ibid.; R. Howard Cricks, "Kinema Technique and Equipment," Ideal Kinema, September 10, 1942, vii.

64. Cricks, "Kinema Technique and Equipment," vii.

65. May, "More Women Projectionists Needed Now," 60.

66. J. Whitnall, "Running the Show-I," Ideal Kinema, October 9, 1941, ix.

67. Ideal Kinema cartoon, September I3, I945, xvii.

68. Ibid.

69. Farmer, The Utility Dream Palace, 216.

70. "Women Call-Up Crisis: Costly Trade Training Is Wasted," Kinematograph Weekly, July 16, 1942, I.

71. "Women Operators," Kinematograph Weekly, II. 
72. "Projectionettes on the Duty Rota," Kinematograph Weekly, 28.

73. "Deferment of Pivotal Women Staff," Kinematograph Weekly, August 20, 1942, I.

74. "Exhibitors Under Fire," Kinematograph Weekly, January I4, 1943, 39.

75. "The Observation Window: Training Older Women," Kinematograph Weekly,

August 27, 1942, 27.

76. Lant, Blackout, II.

77. "Projectionettes on the Duty Rota," Kinematograph Weekly, 28.

78. R. Howard Cricks, "Kinema Technique and Equipment," Ideal Kinema, June I7, 194I, vii.

79. "Male Trouble," Kinematograph Weekly, March 5, 1942, 5; "Lady Valuer Is Kinema Specialist," Kinematograph Weekly, July I, 1943, 19.

8०. William R. Glenn, architect, architectural drawings, Old Kent Road, London Metropolitan Archive, 1935.

81. Producer Sydney Box quoted this figure to Kine Weekly in an article reporting that he was establishing an all-female production unit (Verity Films). "Technicians Called Up: How to Fill the Gaps," Kinematograph Weekly, I.

82. Nicholas Mirzoeff describes how "the right to look is not about seeing" and is about "autonomy, not individualism or voyeurism, but the claim to a political subjectivity and collectivity." Nicholas Mirzoeff, The Right to Look: A Counterhistory of Visuality (London: Duke University Press, 201I), I.

83. Laura Mulvey, "Visual Pleasure and Narrative Cinema," Screen I6, no. 3 (1975): 6-18; John Berger, Ways of Seeing (London: Penguin Books, 1972); Judith R. Walkowitz, City of Dreadful Delight: Narratives of Sexual Danger in Late-Victorian London (London: Virago Press, 1992); Liz Conor, The Spectacular Modern Woman: Feminine Visibility in the rgas (Bloomington: Indiana University Press, 2004).

84. For example, Catherine Hall and Leonore Davidoffs work on family life in England proposes that men inhabited the public realm of civilization and work, while women occupied the private, domestic realm, in which the female body was concealed from sight and thus was safe from male objectification. See Leonore Davidoff and Catherine Hall, Family Fortunes: Men and Women of the English Middle Class, 1780-1850 (London: Hutchinson, 1987).

85. For example, the murder of Miss Florence Nightingale Shore on a train from London to St. Leonards was reported in the national news ("Train Crime Inquest," Daily Telegraph, February 5, 1920, I4), as were the deaths of three women at a film factory ("Girls in Flames Leap from Blazing Film Store," Daily Mirror, September 10, 1927, 3).

86. Lant, "Prologue: Mobile Femininity," 17.

87. H. H., "The Editor's Letter Bag-Cinema Contrasts," 5.

88. Ibid.

89. Cricks, "Kinema Technique and Equipment," Ideal Kinema, June 17, 1941, vii.

90. Christine Gledhill and Gillian Swanson, "Introduction," in Nationalising Femininity, 7.

91. Lant, Blackout, 54.

92. Ibid. 
93. Abram Games, ATS, Imperial War Museum, 1944; Philip Zec, Women of Britain Come Into the Factories, Imperial War Museum, 194I.

94. Clive Uptton, Join the Women's Land Army, Imperial War Museum, I940s.

95. Wartime films, including Night Train to Munich (dir. Carol Reed, UK, 1940), The Gentle Sex (dir. Leslie Howard, UK, 1943), Millions Like Us (dir. Frank Launder and Sidney Gilliat, UK, 1943), A Canterbury Tale (dir. Michael Powell and Emeric Pressburger, UK, 1944), and I Know Where I'm Going! (dir. Michael Powell and Emeric Pressburger, UK, 1945), registered the horizontal plane by simultaneously acknowledging women's elevated status within the public sphere and reminding audiences of men's even higher positions.

96. Matthew Evangelista, Gender, Nationalism and War: Conflict on the Movie Screen (Cambridge: Cambridge University Press, 2011), I3.

97. “Training Women as Projectionists," Ideal Kinema, xi.

98. "Technicians Called Up: How to Fill the Gaps," Kinematograph Weekly, I.

99. Richard Farmer demonstrates that there were some female projectionists still working in cinemas into the 1950 s (see Farmer, The Utility Dream Palace, 226). However, industry-wide calls for men to train as operators, and further evidence of labor shortages in the box, suggest that such instances were rare.

I00. May, "More Women Projectionists Needed Now," 60.

IOI. "Situations Vacant," Lincolnshire Echo, September II, 1944, 2.

I02. "Training for Projectionists," Kinematograph Weekly, September 20, 1945, 43.

103. "Shortage of Skilled Projectionists Feared," Kinematograph Weekly, September 20, 1945, I4.

I04. For example, women commentators reported on, and lauded, the 1942 Beveridge Report (which later underpinned welfare state reforms) as recognition of their civic rights. An unnamed woman writer asserted in a national newspaper that the report was significant because "for the first time in an official document, it describes husband and wife as a team, and treats them as partners." "Message to All Women," Daily Mirror, December 16, 1942, 7 .

105. Judith Mayne, Cinema and Spectatorship (London: Routledge, 1993), 28. 